\title{
Perceived Outcomes of Spiritual Healing: Results from a Prospective Case Series
}

\author{
Michael Teut Florian Besch Claudia M. Witt Barbara Stöckigt \\ Institute for Social Medicine, Epidemiology and Health Economics, Charité - Universitätsmedizin Berlin, \\ Berlin, Germany
}

\begin{abstract}
Keywords
Spiritual healing · Qualitative methods · Quantitative methods . Mixed methods . Complementary and alternative medicine $\cdot$ Outcomes
\end{abstract}

\begin{abstract}
Background: The aims of this pilot study were to observe perceived outcomes of spiritual healing in Germany. Patients and Methods: In this prospective case study, we performed qualitative interviews with clients and healers about perceived outcomes of spiritual healing treatments. A directed qualitative content analysis was used. In addition, we applied questionnaires (WHOQOL-BREF, General Self-Efficacy Scale, Sense of Coherence 13, SpREUK-15, intensity of complaints on visual analogue scale) at baseline and after week 1 , month 2 and month 6 which were analysed descriptively. Results: Seven healers and 7 clients participated, 42 interviews were analysed. In the interviews, the clients described positive body sensations, greater relaxation and well-being as short-term effects of healing treatments. Perceived longer-term effects were related to making significant life changes, creating new meanings, activating resources and improving social relationships. Patients in pain described a reduction of pain intensity. In the questionnaires, the clients reported improvements in quality of life and self-efficacy, to a smaller extent improvements of intensity of complaints and sense of coherence. Conclusion: The results from this pilot study could be useful to choose outcomes of future prospective studies with a larger sample: qualitative assessments combined with global and broad quantitative outcomes such as quality of life, self-efficacy and intensity of complaints could be applied.

(c) 2019 S. Karger AG, Basel
\end{abstract}

\section{Wahrgenommene Effekte spirituellen Heilens: Ergebnisse einer prospektiven Fallserie}

\section{Schlüsselwörter}

Spirituelles Heilen · Qualitative Methoden · Quantitative Methoden · Methodenkombination · Komplementäre und alternative Medizin - Behandlungsergebnisse

\section{Zusammenfassung}

Hintergrund: Ziel dieser Pilotstudie war es, subjektiv wahrgenommene Effekte des spirituellen Heilens qualitativ und quantitativ zu erfassen. Patienten und Methoden: In dieser prospektiven Pilotstudie wurden über 6 Monate qualitative Interviews mit Klienten und Heilern über wahrgenommene Effekte spiritueller Heilbehandlungen geführt und auf Basis einer qualitativen Inhaltsanalyse ausgewertet. Ergebnisse wurden zusätzlich mit Fragebögen (WHOQOL-BREF, General Self-Efficacy Scale, Sense of Coherence 13, SpREUK-15, Beschwerdeintensität auf visueller Analogskala) zu Studienbeginn und nach der Woche 1, Monat 2 und Monat 6 erfasst. Ergebnisse: Sieben Heiler und 7 Klienten nahmen an dieser Studie teil, 42 Interviews wurden analysiert. Klienten beschrieben als kurzfristige Effekte der Heilbehandlungen positive Körperempfindungen, mehr Entspannung und Wohlbefinden. Die längerfristig wahrgenommenen Effekte standen im Zusammenhang mit signifikanten Veränderungen des Lebens, neuen Deutungen, Ressourcenaktivierung und der Verbesserung sozialer Beziehungen durch die Klienten. Klienten mit Schmerzen beschrieben eine Verringerung der Schmerzintensität. In den Fragebögen zeigten

\section{KARGER}

(c) 2019 S. Karger AG, Basel 
sich Verbesserungen der Lebensqualität und der Selbstwirksamkeit, zu einem geringeren Ausmaß Verbesserungen der Beschwerdeintensität und des Kohärenzgefühls. Schlussfolgerung: Die Ergebnisse dieser Pilotstudie könnten nützlich sein, um Endpunkte für künftige prospektive Studien mit einem größeren Stichprobenumfang zu wählen: qualitative Analysen in Kombination mit Fragebögen, die globale und umfassende Aspekte wie Lebensqualität, Selbstwirksamkeit und Intensität der Beschwerden erfassen, sind unserer Ansicht nach am besten geeignet.

๑) 2019 S. Karger AG, Basel

\section{Introduction}

A healer, often called a "spiritual" healer, is defined as a person who exercises the practices of laying hands on, prayers, and/or meditation while most importantly considering himself connected to a transcendent or spiritual power [1-4]. Due to globalization, the techniques and methods of healing have diversified and are now derived from various spiritual and religious practices [5]. Understanding the field of healing and its practitioners in the German context is difficult due to its variety [5-7]. The field of healing in Germany is often described by the term "Szene" (scene), which denotes an indistinct field with a limited degree of organization and a loose, translocal community [5]. From a medical researchers' perspective, spiritual healing can be described as a "blind spot," not only in the German health system. Frequency and circumstances of use, effectiveness and especially the relevance of its use to patients, but also potential risks have not been reliably investigated nationally and internationally. This may be due to the fact that spiritual healing practices are often perceived as quackery by health professionals. Spiritual healing does also include religious aspects, which is difficult to handle by medical professionals. However, in our experience, a wide range of spiritual self-help techniques are applied by patients, mostly outside the official medical system. The importance is also reflected in the medical self-help literature that extensively covers healing practices dealing with hand and energy healing (e.g., reiki), prayer, shamanism or spiritual healing practices derived from traditional therapies such as qigong, tai chi or yoga.

In a recent qualitative study on spiritual healing in Germany, we focused on the emic perspective to better understand what it means to be a healer and to experience healing treatments as a client. We have previously interviewed and observed participants who considered themselves healers and their clients and reported their subjective experiences, perceived outcomes and explanations [8], biographies [3] and therapeutic relationships [4].
In that study, healers and their clients reported perceived outcomes of healing treatments including: positive body sensations such as "warmth" or "light," increased well-being, more positive emotions and symptomatic relief of medical complaints [8]. Clients and healers described themselves as being connected to transcendent sources (e.g., god, a universal energy, light), which empowered them to change. Clients reported that they made personal changes by going through a spiritual healing process, reframing their concepts of health, disease, reality and identity and reported that they reconsidered what they considered to be important, and subsequently changed their lives.

A limitation of our former cross-sectional qualitative case study was a potential community bias (e.g., following recommendations in a healer network) and a potential selection of clients with successful healing stories by their healers. We were unsure whether most clients consulting a healer undergo similar experiences as were described in our previous study. We were also interested in how the perceived healing process would develop over time.

Based on our former findings, we planned to observe the outcomes of spiritual healing prospectively in a pilot case study qualitatively. In addition, we wanted to see whether previously identified quantitative questionnaires measure changes when applied in this setting.

The aim of this study was to (1) qualitatively observe perceived client-reported outcomes of spiritual healing before and after the healing procedure in interviews and (2) to triangulate the qualitative data with data from validated questionnaires.

\section{Methods}

Design

We used a non-controlled, exploratory prospective case study design with a mainly qualitative research focus and conducted interviews with clients and healers. In addition, a set of quantitative questionnaires was distributed to the clients. The study was approved by the ethics committee of the Charité - Universitätsmedizin Berlin (EA1/238/10; 29.07.2013).

\section{Sample}

A snowball sampling technique was used to recruit healers [9]. This technique is useful for recruiting hidden populations that are difficult to access. We first contacted the healers from our first study and asked them to participate. We also contacted new healers, who were identified through German healer organizations with membership lists and a Google homepage search (search terms: "Geistheilung," "Geistheiler" and "place"). Healers wishing to participate in our study were asked to invite new clients to participate and contact us prior to the first healing session if interested. Interested clients were contacted by our researchers by telephone and asked to participate. Participating clients were then visited in person and included after informed consent had been given. We paid an expense allowance of EUR 100 each to healers and clients for participating in the interviews and completing the questionnaires. 
Table 1. Interview guidelines

Questions to the healer

Introduction

I am glad that you agreed to participate in our study. Before starting with questions, do you have questions?

\section{Starting}

What was your impression of the last treatment(s)? Were

there more treatments in between?

\section{Treatment}

Please talk about the treatment. Did you prepare for treatment? How did you experience the healing treatment? Any specifics?

\section{Relationship}

How did you experience the client? What impression did you get? What did you note? How would you describe your relationship with the client? What has changed? Any specifics?
Questions to the clients

Introduction

I am glad that you agreed to participate in our study. Before starting with questions, do you have questions?

\section{Starting}

How are you now, after the treatment(s)?

\section{Treatment}

Please describe what happened in the treatment(s). Have there been more treatments? What happened? How did you experience the healing treatment(s)? What did you feel? Any specifics?

\section{Relationship}

How did you experience your relationship with the healer? How would you describe this relationship now? What is important? Did the relationship change over time?

\section{Expectations}

Why did you consult the healer? What do you expect from the treatment? Did you prepare for the treatment? Why did you continue to consult the healer? Did your expectations change over time? How?

\section{Process of healing}

Has something changed in the client? What? Has there been a point of change? Did your treatment help the client? What exactly has changed? Why did the client come back to you? Do you have any ideas/concepts about how to continue treating this client? What is the role of the client? What about his social surrounding?

\section{Process of healing}

How are you now after the treatment(s)? Have you experienced changes in symptoms or complaints? What exactly has changed? When did this change begin? Was there a point of change? What about symptoms and complaints? How exactly did they change? Did your attitude towards your complaints change?

Did the treatment experience have any consequences for your daily life? Have there been any changes in your life? What exactly?

Did your treatment experience have a spiritual or religious dimension?

Do you actively support your healing? If yes, how? What about your social surroundings?

\section{Questionnaires}

How did you like the questionnaires?

Did you understand them, did they apply to your situation? What did you like, what did you dislike? What about combining interviews and questionnaires?

\section{End of interview \\ Do you want to add anything you consider important? Looking back, what was most important in the last treatments? \\ Do you have any questions? Thank you very much for participating in this interview!}

\section{End of interview}

Do you want to add anything you consider important? Looking back, what was most important in the last treatments?

Do you have any questions? Thank you very much for participating in this interview!
The following inclusion criteria were applied. Healers should be at least 18 years of age or older and provide written informed consent. Clients should be 18 years of age or older, have had no previous treatment by their new healer and provide written informed consent.

The following exclusion criteria applied: healers with lack of knowledge of the German language; clients suffering from diseases that would not allow them to participate in the study (e.g., being unable to speak, cognitive impairment, loss of orientation).

\section{Outcomes}

Clients and healers were interviewed both after the first treatment, at month 2 and month 6 . Our interview guideline had a semi-structured approach and consisted of open-ended questions for healers and clients (Table 1). We intentionally did not interview clients at baseline because we suspected that an in-depth interview with a researcher might influence their expectation of, perception of and meaning taken from the first healing session. Interviews were digitally recorded and transcribed verbatim including a pseudonymization of personal data. The text files were then add- 


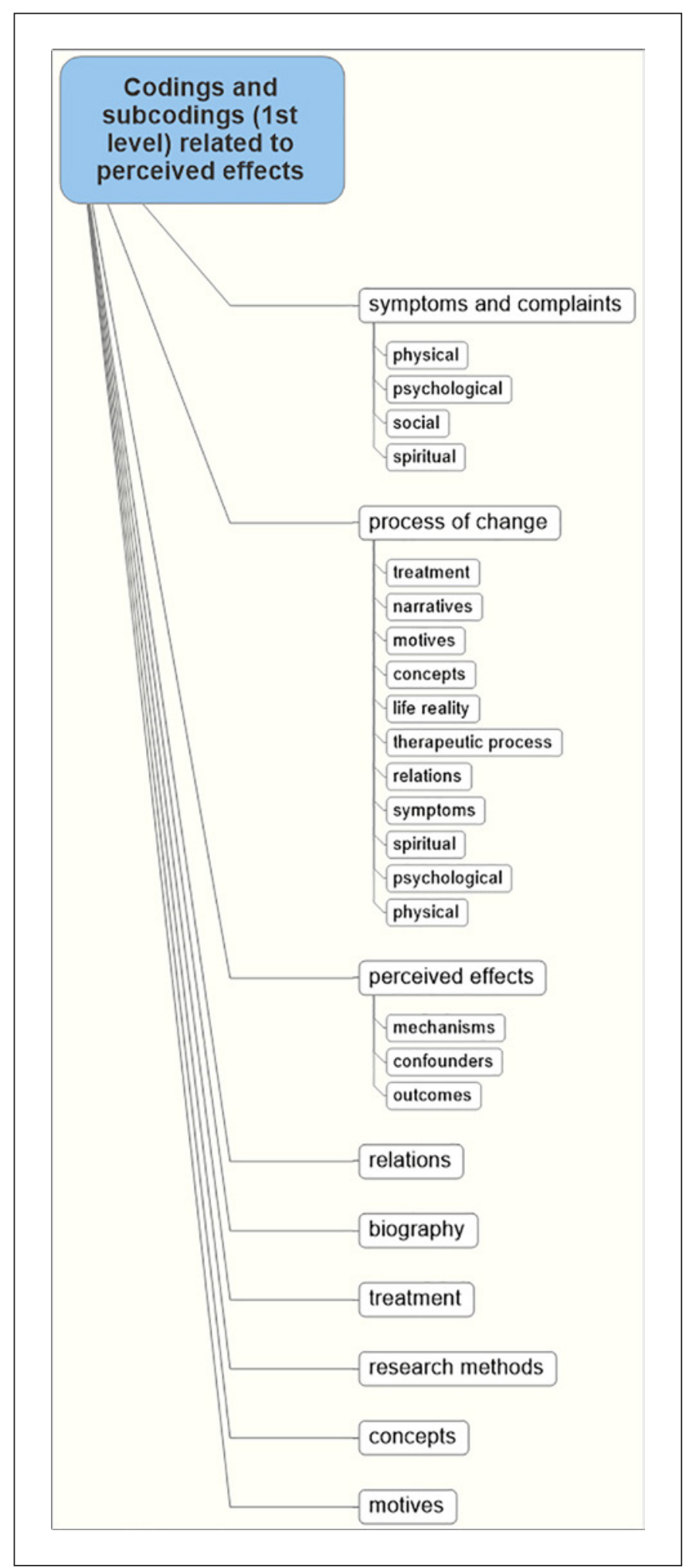

Fig. 1. Main codes and subcodes related to perceived effects and process of change.

ed to a MAXQDA database for the qualitative analysis. Written memos of the interviews provided further information on the setting, non-verbal expressions of the interviewees, as well as the researchers' subjective experiences.
Questionnaires were distributed to clients at baseline, after week 1 (after the first treatment session), at month 2 and at month 6 . Interviews were performed during client visits at week 1 , month 2 and month 6 . If a personal visit was not possible, a telephone interview was conducted. Based on the results of our previous qualitative study [8], we chose the following questionnaires to quantitatively document client outcomes: average intensity of complaints in the last week on a visual analogue scale $(0-100 \mathrm{~mm} ; 0 \mathrm{~mm}=$ no complaints, $100 \mathrm{~mm}$ = worst intensity of complaints), health-related quality of life (WHOQOL-BREF [10]), General Self-Efficacy Scale [11], spiritual and religious attitudes towards dealing with illness (SpREUK-15 [12, 13]), sense of coherence (SOC-13 [1417]) and Consultation and Relational Empathy (CARE [18], based on [19]).

\section{Data Analyses}

Qualitative analyses were based on a directed qualitative content analysis [20] using MAXQDA software (MAXQDA 10, Berlin). A combination of deductive and inductive coding strategies was used. The main categories and first level of subcategories for coding the data were predefined by the research team according to our research questions. The coding of the following subcategories allowed for a continuous process of extracting codes from conducted interviews and discussing them among the team members. The team, consisting of three medical doctors and one anthropologist, discussed the data collection and analyses every 4 months in 1-day research workshops. All coded interviews were reviewed and co-coded by randomly assigned members of the research team to improve the quality and validity of the analyses. The codes and subcodes relevant to the content analysis of perceived effects and process of change are shown in Figure 1 (subcodes relevant to other analyses such as therapeutic relationship or biography are not shown).

The quantitative data derived from the questionnaires were analysed descriptively (SPSS 22.0) using means, standard deviations and proportions (\%) for baseline, week 1, month 2 and month 6 .

\section{Results}

\section{Recruitment and Sample}

Altogether, 22 healers identified by our search were asked to participate. Of those, we were able to recruit 2 healers from our former study and 5 new healers. Reasons for not participating in the study included the following: too few clients in therapy, personal reasons, study expected to be too time intensive, having other fields of interest. Three healers did not want to be engaged in our questionnaire-based outcome assessment. The 7 participating healers asked 10 clients to participate, of whom 7 agreed to participate. Reasons for non-participation were distrust of the questionnaires for 2 clients and not attending the planned healing session for 1 client. The group of healers consisted of 3 men and 4 women (mean age \pm SD $55.3 \pm 5.9$ years). Among them were 2 non-medical complementary medicine practitioners (German: "Heilpraktiker"), a family physician, a dental technician, a social worker, a seamstress and a businesswoman. Most healers practiced a mix of healing methods (healing with hands $n=5$; working with spiritual agents/superhuman beings 
Table 2. Client level triangulation of patient-reported qualitative and quantitative outcomes

\begin{tabular}{|c|c|c|c|c|c|}
\hline Client & $\begin{array}{l}\text { Age, } \\
\text { gender, } \\
\text { profession }\end{array}$ & $\begin{array}{l}\text { Reasons for } \\
\text { consultation }\end{array}$ & $\begin{array}{l}\text { Healing } \\
\text { treatments }\end{array}$ & Qualitative outcomes & $\begin{array}{l}\text { Quantitative outcomes } \\
\text { reported }\end{array}$ \\
\hline A_H4_K1 & $\begin{array}{l}61 \text { years, } \\
\text { female, } \\
\text { housewife }\end{array}$ & $\begin{array}{l}\text { Loss of eyelashes, dry } \\
\text { skin, fear of meeting } \\
\text { other people, } \\
\text { compulsion to control } \\
\text { her eyelashes in } \\
\text { mirror }\end{array}$ & Hand healing & $\begin{array}{l}\text { Direct perceived effects of healing: } \\
\text { relaxation and warm body sensations, } \\
\text { tingling, feeling of lightness } \\
\text { Long-term perceived effects: } \\
\text { fluctuation of complaints, short-term } \\
\text { ameliorations after treatments; } \\
\text { reframing of psychological and social } \\
\text { situations: gained ability to build up } \\
\text { more distance from family, accepting } \\
\text { her disease }\end{array}$ & $\begin{array}{l}\text { Excluded from analysis for } \\
\text { filling out all questionnaires at } \\
\text { all time points with maximum } \\
\text { values }\end{array}$ \\
\hline A_H6_K1 & $\begin{array}{l}50 \text { years, } \\
\text { female, } \\
\text { teacher }\end{array}$ & $\begin{array}{l}\text { Chronic back pain, } \\
\text { atopic eczema, } \\
\text { anxiety, increase in } \\
\text { well-being, to find } \\
\text { balance took a } \\
\text { 6-month sabbatical }\end{array}$ & $\begin{array}{l}\text { Treatment by two } \\
\text { healers (only one } \\
\text { in study), hand } \\
\text { healing meridian } \\
\text { acupressure, } \\
\text { manual therapy }\end{array}$ & $\begin{array}{l}\text { Direct perceived effects: } \\
\text { sensation of warmth, relaxation, filling } \\
\text { up with energy, restoring energy } \\
\text { balance } \\
\text { Long-term perceived effects: } \\
\text { more light and inner harmony, more } \\
\text { happiness; } \\
\text { strong reduction of back pain; } \\
\text { less atopic eczema; } \\
\text { being more balanced (more centred); } \\
\text { integration of different parts of her } \\
\text { personality, integrating her roles as } \\
\text { mother and teacher; } \\
\text { more control of fears }\end{array}$ & $\begin{array}{l}\text { WHOQOL physical domain +; } \\
\text { WHOQOL psychological } \\
\text { domain +; } \\
\text { WHOQOL social } \\
\text { relationships +; } \\
\text { WHOQOL environment } \\
\text { domain +; } \\
\text { VAS intensity of complaints -; } \\
\text { General Self-Efficacy +; } \\
\text { Sense of Coherence } 13 \text { +; } \\
\text { spiritual and religious } \\
\text { attitudes in dealing with } \\
\text { sickness/search + }\end{array}$ \\
\hline B_H9_H10_K1 & $\begin{array}{l}53 \text { years, } \\
\text { female, } \\
\text { technician }\end{array}$ & $\begin{array}{l}\text { Social problems, } \\
\text { search for partner, } \\
\text { family problems, after } \\
\text { being financially } \\
\text { deceived by a friend }\end{array}$ & $\begin{array}{l}\text { Incorporation, } \\
\text { hand healing }\end{array}$ & $\begin{array}{l}\text { Direct perceived effects: } \\
\text { something "drawn out of her chest", } \\
\text { feels lighter and liberated; more energy } \\
\text { Long-term perceived effects: } \\
\text { more relaxed; } \\
\text { being stronger; } \\
\text { learned much about herself; } \\
\text { understands her problems better now; } \\
\text { changed her social life; } \\
\text { being in love now; } \\
\text { improved her financial status }\end{array}$ & $\begin{array}{l}\text { WHOQOL psychological } \\
\text { domain +; } \\
\text { WHOQOL social } \\
\text { relationships +; } \\
\text { General Self-Efficacy +; } \\
\text { Sense of Coherence } 13+\text {; } \\
\text { spiritual and religious attitudes } \\
\text { in dealing with sickness/trust + }\end{array}$ \\
\hline B_H11_K1 & $\begin{array}{l}45 \text { years, } \\
\text { female } \\
\text { beautician }\end{array}$ & $\begin{array}{l}\text { Rheumatoid arthritis, } \\
\text { side effects of } \\
\text { medication }\end{array}$ & $\begin{array}{l}\text { Hand healing, } \\
\text { medial healing, } \\
\text { soul retrieval }\end{array}$ & $\begin{array}{l}\text { Direct perceived effects: } \\
\text { sensation of warmth, relaxation, } \\
\text { calmness } \\
\text { Long-term perceived effects: } \\
\text { reduction of pain in the first weeks, } \\
\text { then increase of rheumatic pain - went } \\
\text { into rehabilitation treatment (which } \\
\text { did not work well); } \\
\text { understood her childhood experiences } \\
\text { better; } \\
\text { more happiness; } \\
\text { reorganized her life in a positive way; } \\
\text { more hope, more relaxed; } \\
\text { less fear of disease; } \\
\text { more spiritually oriented } \\
\text { (effects were related to a combination of } \\
\text { spiritual healing and conventional } \\
\text { rheumatological treatments) }\end{array}$ & $\begin{array}{l}\text { WHOQOL overall perception } \\
\text { of quality of life +; } \\
\text { WHOQOL overall perception } \\
\text { of health+; } \\
\text { WHOQOL physical domain +; } \\
\text { WHOQOL Psychological } \\
\text { domain +; } \\
\text { WHOQOL social } \\
\text { relationships +; } \\
\text { WHOQOL Environment } \\
\text { domain +; } \\
\text { VAS intensity of complaints -; } \\
\text { General Self-Efficacy +; } \\
\text { Sense of Coherence 13 + } \\
\text { (week 1) - (6 months); } \\
\text { spiritual and religious } \\
\text { attitudes in dealing with } \\
\text { sickness/total +; } \\
\text { spiritual and religious attitudes } \\
\text { in dealing with sickness/trust + }\end{array}$ \\
\hline
\end{tabular}


Table 2 (continued)

\begin{tabular}{|c|c|c|c|c|c|}
\hline Client & $\begin{array}{l}\text { Age, } \\
\text { gender, } \\
\text { profession }\end{array}$ & $\begin{array}{l}\text { Reasons for } \\
\text { consultation }\end{array}$ & $\begin{array}{l}\text { Healing } \\
\text { treatments }\end{array}$ & Qualitative outcomes & $\begin{array}{l}\text { Quantitative outcomes } \\
\text { reported }\end{array}$ \\
\hline B_H13_K1 & $\begin{array}{l}54 \text { years, } \\
\text { female, } \\
\text { office worker }\end{array}$ & $\begin{array}{l}\text { Depression, } \\
\text { psychosomatic } \\
\text { complaints (chest, } \\
\text { stomach), feeling } \\
\text { psychologically } \\
\text { blocked }\end{array}$ & $\begin{array}{l}\text { Aura treatment, } \\
\text { clairvoyant, } \\
\text { working with } \\
\text { angels }\end{array}$ & $\begin{array}{l}\text { Direct perceived effects: } \\
\text { pressure on chest, pain in back, inner } \\
\text { pictures (third eye), solution of } \\
\text { blockades, weeping } \\
\text { Long-term perceived effects: } \\
\text { understood that her complaints were } \\
\text { due to the death of her father; } \\
\text { feels liberated, more energy, new ideas, } \\
\text { positive approach to life; } \\
\text { relapse of symptoms after } 2 \text { months, } \\
\text { but with altered meaning; now realized } \\
\text { that she be herself more and allow for } \\
\text { her feelings }\end{array}$ & $\begin{array}{l}\text { WHOQOL overall perception } \\
\text { of quality of life +; } \\
\text { WHOQOL physical domain +; } \\
\text { WHOQOL psychological } \\
\text { domain +; } \\
\text { WHOQOL social } \\
\text { relationships +; } \\
\text { WHOQOL environment } \\
\text { domain +; } \\
\text { General Self-Efficacy +; } \\
\text { Sense of Coherence } 13+\end{array}$ \\
\hline C_H2_K2 & $\begin{array}{l}52 \text { years, } \\
\text { female, } \\
\text { educator }\end{array}$ & $\begin{array}{l}\text { Hip osteoarthritis, } \\
\text { pain, mourning (death } \\
\text { of father) }\end{array}$ & $\begin{array}{l}\text { Aura therapy, } \\
\text { hand healing } \\
\text { shiatsu, } \\
\text { therapeutic talk }\end{array}$ & $\begin{array}{l}\text { Direct perceived effects: } \\
\text { sensation of warmth, seeing colours, } \\
\text { being more centred, more energy, } \\
\text { trust in higher spiritual forces } \\
\text { Long-term perceived effects: } \\
\text { pain reduction; } \\
\text { does not need pain medication any } \\
\text { more; } \\
\text { emotionally stabilized; } \\
\text { more mindful; } \\
\text { took a foster child to care for home; } \\
\text { started regular gymnastics; } \\
\text { started a diet; } \\
\text { gained self-control }\end{array}$ & $\begin{array}{l}\text { WHOQOL overall perception } \\
\text { of quality of life +; } \\
\text { WHOQOL overall perception } \\
\text { of health +; } \\
\text { WHOQOL physical domain +; } \\
\text { WHOQOL psychological } \\
\text { domain +; } \\
\text { WHOQOL environment } \\
\text { domain +; } \\
\text { General Self-Efficacy +; } \\
\text { Sense of Coherence } 13+\end{array}$ \\
\hline C_H2_K3 & $\begin{array}{l}55 \text { years, } \\
\text { female, } \\
\text { retired }\end{array}$ & $\begin{array}{l}\text { Severe depression, } \\
\text { disturbed sleep }\end{array}$ & $\begin{array}{l}\text { Aura therapy, } \\
\text { hand healing } \\
\text { shiatsu, } \\
\text { therapeutic talk }\end{array}$ & $\begin{array}{l}\text { Direct perceived effects: } \\
\text { sensation of warmth, stopping of } \\
\text { brooding, nearly slept, relaxed, } \\
\text { imagined a land behind the rainbow } \\
\text { and meeting her grandparents there } \\
\text { Long-term perceived effects: } \\
\text { better sleep ( } 2 \text { months); } \\
\text { after } 6 \text { months increase in depression } \\
\text { and treatment in a psychiatric ward; } \\
\text { belief in spiritual healing increased }\end{array}$ & $\begin{array}{l}\text { WHOQOL physical domain +; } \\
\text { WHOQOL psychological } \\
\text { domain }+ \text {; } \\
\text { spiritual and religious } \\
\text { attitudes in dealing with } \\
\text { sickness/total +; } \\
\text { spiritual and religious } \\
\text { attitudes in dealing with } \\
\text { sickness/trust +; } \\
\text { spiritual and religious } \\
\text { attitudes in dealing with } \\
\text { sickness/search +; } \\
\text { spiritual and religious } \\
\text { attitudes in dealing with } \\
\text { sickness/reflection + }\end{array}$ \\
\hline
\end{tabular}

VAS, visual analogue scale; +, increase in scores; -, decrease in scores over the 6-month observation period; stable or inconsistent outcomes were not listed.

$n=3$; energy healing $n=4)$. In total, 22 interviews with healers were conducted. The interviews took place in the healers' clinics or their homes; the interviews took between 30 and 90 min of time. Interviews were taken by B.S., M.T. and F.B.

The 7 participating clients were all women (mean age \pm SD $53.1 \pm 4.9$ years). Their professions included 5 employees, 1 housewife and 1 retired woman. Six clients suffered from physical symptoms, such as pain for 4 of the women ( 2 with osteoarthritis and 2 with back pain). Six clients described mental concerns (2 with depressive symptoms, 2 with anxiety, 2 with social problems). In total, 20 interviews with clients were conducted. The interviews took place in the patients' homes; the interviews had a length between 30 and $90 \mathrm{~min}$. In a few cases, patients were difficult to reach for follow-up interviews, and in those cases, interviews were taken by telephone and also audiorecorded. Interviews were taken by B.S., M.T. and F.B.

In total, 20 healing treatments were carried out during the observation period. The average number of treatments per client \pm SD was $2.9 \pm 1.7$. The longest treat- 
Table 3. Descriptive analyses of perceived outcomes of spiritual healing at baseline and at week 1 , month 2 and month 6 ( $n=6$ clients)

\begin{tabular}{|c|c|c|c|c|}
\hline & Baseline & Week 1 & Month 2 & Month 6 \\
\hline Intensity of complaints (last 7 days) VAS (0-100) & $53.9 \pm 21.8$ & $44.4 \pm 27.6$ & $26.5 \pm 28.2$ & $47.7 \pm 25.1$ \\
\hline \multicolumn{5}{|l|}{ WHOQOL-BREF } \\
\hline Physical domain & $60.7 \pm 23.3$ & $73.5 \pm 24.2$ & $78.6 \pm 20.0$ & $78.0 \pm 19.0$ \\
\hline Psychological domain & $48.2 \pm 13.8$ & $59.5 \pm 18.3$ & $66.7 \pm 17.5$ & $68.1 \pm 18.9$ \\
\hline Social relationships domain & $56.0 \pm 9.3$ & $56.0 \pm 17.2$ & $72.6 \pm 13.4$ & $70.8 \pm 15.6$ \\
\hline Environment domain & $72.3 \pm 11.5$ & $77.2 \pm 12.2$ & $78.1 \pm 17.5$ & $81.3 \pm 14.4$ \\
\hline \multicolumn{5}{|l|}{ Overall perception of quality of life } \\
\hline Very poor & $0(0 \%)$ & $0(0 \%)$ & $0(0 \%)$ & $0(0 \%)$ \\
\hline Poor & $1(14.3 \%)$ & $0(0 \%)$ & $0(0 \%)$ & $0(0 \%)$ \\
\hline Neither poor nor good & $4(57.1 \%)$ & $4(57.1 \%)$ & $3(42.9 \%)$ & $1(14.3 \%)$ \\
\hline Good & $2(28.6 \%)$ & $2(28.6 \%)$ & $2(28.6 \%)$ & $4(57.1 \%)$ \\
\hline Very good & $0(0 \%)$ & $1(14.3 \%)$ & $2(28.6 \%)$ & $1(14.3 \%)$ \\
\hline \multicolumn{5}{|l|}{ Overall perception of health } \\
\hline Very dissatisfied & $1(14.3 \%)$ & $1(14.3 \%)$ & $0(0 \%)$ & $0(0 \%)$ \\
\hline Dissatisfied & $3(42.9 \%)$ & $2(28.6 \%)$ & $3(42.9 \%)$ & $2(28.6 \%)$ \\
\hline Neither satisfied nor dissatisfied & $1(14.3 \%)$ & $0(0 \%)$ & $1(14.3 \%)$ & $0(0 \%)$ \\
\hline Satisfied & $2(28.6 \%)$ & $3(42.9 \%)$ & $3(42.9 \%)$ & $4(57.1 \%)$ \\
\hline Very satisfied & $0(0 \%)$ & $1(14.3 \%)$ & $0(0 \%)$ & $0(0 \%)$ \\
\hline General Self-Efficacy Scale (Schwarzer) & $24.4 \pm 4.9$ & $28.0 \pm 4.1$ & $30.4 \pm 6.5$ & $30.5 \pm 7.1$ \\
\hline Sense of Coherence (SOC-13) & $49.3 \pm 11.6$ & $56.6 \pm 12.2$ & $59.7 \pm 12.8$ & $58.3 \pm 19.0$ \\
\hline \multicolumn{5}{|c|}{ Spiritual and religious attitudes in dealing with illness (SpREUK) } \\
\hline Total score & $70.5 \pm 30.4$ & $74.3 \pm 27.2$ & $72.6 \pm 30.4$ & $79.2 \pm 22.2$ \\
\hline Trust & $65.0 \pm 30.0$ & $72.1 \pm 29.8$ & $72.1 \pm 34.0$ & $78.3 \pm 25.4$ \\
\hline Search & $69.3 \pm 34.5$ & $67.9 \pm 33.6$ & $70.0 \pm 35.5$ & $79.2 \pm 22.2$ \\
\hline Reflection & $77.1 \pm 29.8$ & $82.9 \pm 23.2$ & $75.7 \pm 28.2$ & $81.7 \pm 20.4$ \\
\hline Consultation and Relational Empathy (CARE) & $\mathrm{n} / \mathrm{a}$ & $45.7 \pm 5.3$ & $47.0 \pm 5.1$ & $45.7 \pm 6.0$ \\
\hline
\end{tabular}

Values are presented as means \pm SD or numbers (\%). VAS, visual analogue scale.

ment included 5 sessions over 6 months; the shortest treatment was a single session ( 3 clients). One client continued the therapy with another healer who was not included in this study, but we continued interviewing that client.

\section{Outcomes}

Table 2 summarizes the individual qualitative outcomes and changes in the quantitative assessments for each client. Table 3 contains the results of the quantitative descriptive analysis. Client A_H4_K1 was excluded from the quantitative analysis because of concerns with the validity of her data; she reported maximum values for all questionnaires at all time points.

Six out of 7 clients described both mental and physical symptoms and complaints at the beginning and throughout the treatment process. Four of them made a direct link between the mental and physical complaints.

Two clients had depression at baseline, and 2 clients had anxiety and/or obsessive-compulsive disorder. A client described her mental illness as a result of the arthritis complaint that affected her self-confidence and social behaviour. Four patients described psychological, emotional or social improvements Two clients did not experience sustained, long-term mental changes during therapy. These 2 clients did not experience any lasting improvement in their physical symptoms either (back pain or ocular skin disease).

All but 1 client had physical symptoms and complaints. Four of the clients were pain patients with detailed previous, unsuccessful conventional medical therapy, 2 with osteoarthritis and 2 with back pain. Regarding her physical complaints (back pain) only 1 client did not experience any changes in the course of the study; all the others reported improvements. In 2 clients, the course of the symptoms was very variable. The above-mentioned client FB_H4_K1 with the eye and skin disease regularly experienced an improvement in their symptoms after the treatment, sometimes to a very noticeable degree.

The reported individual outcomes from the qualitative interviews were summarized as short-term (related directly to the actual healing treatments) or longer-term (describing longer-lasting changes or changes that occurred within the 6 months of healing treatments and were perceived by clients as effects of the healing treatments). 


\section{Summary of Perceived Short-Term \\ Qualitative Outcomes}

Most clients described the direct experience of the healing treatments as: experiences of relaxation, well-being and feeling positive body sensations such as warmth, lightness, becoming calm (Table 2). Clients also described the feeling of "filling up with energy," "restoring energy balance" and feeling more centred.

... and then I just noticed how the whole crap left the body, as if ... [everything was] ... rinsed out. I had that feeling. But with a comforting warm feeling. The whole thing took over two hours. But I felt great. And I feel good too, I have to say quite honestly. [B_H13_K1, client]

This lying on the back. This relaxed me anyway, then came the tears and then came this absolute letting go. [A_H6_K1, client]

\section{Summary of Perceived Longer-Term \\ Qualitative Outcomes}

The most important perceived and described longerterm effects were those related to changes the clients made in their lives, new meanings they found, resources they activated and new abilities they developed or gained that they related to the healing treatments. Table 2 provides an overview of the details for each individual client. Many of those outcomes were related to each other. Clients described the following changes due to the healing treatments: being more accepting of their disease, being able to distance themselves from family problems, being able to integrate different parts of their personalities, learning to better understand and accept themselves, changing their social life, improving financial status, reorganizing life in a positive way, feeling more spiritual or mindful, falling in love, taking in a foster child to care for at home, and starting a diet.

Well, now I'm full of verve, I can now pinpoint decisions, which was not possible before. I have regained the joy of life again. I did not have it before. (...) And I have everything that I have planned for this year, (...) I pushed everything. I have done everything. [B_ H13_K1, client]

Yes, that gives me courage and strength and joie de vivre, so desire to attack life, to tackle things. Just like now the foster child, who has just entered my life and I'm getting involved. [C_H2_K2, client]

At some point then a rethinking took place and then I have changed my whole life peu à peu in the right direction, I would say now. And that works quite well. Yes. And as I said, now the [treatment] is a week ago and I feel like I've stepped out of the treatment much stronger, definitely. I am walking! I did not know that was possible before either. [B_H13_K1, client]

Out of the 4 clients suffering from pain, 3 clients described a relevant reduction in pain. Two clients were able to stop taking their pain medication and attributed that to the healing treatments. Altogether, the clients considered the changes in their lives and the development of a new understanding of their symptoms to be more important than symptomatic relief.

[The back] is also better. Goes dazzling! Everything feels very different. (...) And I also play quite differently now table tennis (...) everything is much freer from the movements [ago]. [A_H6_K1, client]

\section{Quantitative Outcomes}

Table 3 shows the descriptively analysed pre-post data of the questionnaires used for 6 clients.

The intensity of complaints occurring in the previous 7 days on the visual analogue scale $(0-100 \mathrm{~mm}, 0=$ absent, $100 \mathrm{~mm}=$ maximum intensity) decreased from $53.9 \pm$ 21.8 at baseline to $26.5 \pm 28.2$ after 2 months but returned to $47.7 \pm 25.1$ after 6 months. This finding indicates that the clients reported a relevant reduction of symptom intensity after 8 weeks, but this reduction did not persist to 6 months.

The WHOQOL-BREF questionnaires showed global improvements in quality of life over time across the physical, psychological and social relationship domains. However, no improvements were reported for the environmental domain. In addition, the client's overall perception of quality of life improved over time. Interestingly, all 6 clients reported improvements in the quality of life domains at least at one time point (Table 2), with improvements in the psychological and social relations domains being the most common reported.

On the General Self-Efficacy Scale (Schwarzer) clients reported an improvement from $24.4 \pm 4.9$ at baseline to $30.4 \pm 6.5$ after 2 months which persisted to month 6 . Table 2 shows that improvements were reported by 5 out of 6 clients.

On the Sense of Coherence Questionnaire (SOC-13) a small improvement from baseline ( $49.3 \pm 11.6)$ to week 1 $(56.6 \pm 12.2)$ was reported and persisted throughout the follow-up period. Of the 6 clients, 4 showed individual improvements over time.

On average, the clients reported little change in spiritual and religious attitudes in dealing with illness (SpREUK). There were improvements in the search and trust domains from baseline through the 6 months of follow-up. However, due to the large standard deviations in this small study population, these changes should be interpreted with caution.

At the individual level, it is interesting to see that client C_H2_K2, who otherwise showed no longer-term improvements, improved on all aspects of the SpREUK questionnaire (Table 3 ).

The Consultation and Relational Empathy (CARE) scores remained quite stable, with mean scores between 45 and 47. No assessment was conducted at baseline as there was not yet a rapport between the clients and healers. 


\section{Discussion}

In the interviews, all clients described short-term effects experienced within the treatment or directly after the treatments such as increase in relaxation, well-being and positive body sensations. The most important longterm effects perceived by 6 of the 7 clients were related to making significant life changes, creating new meanings, activating resources and improving social relationships. These effects were also reflected in the quantitative data with the most relevant changes relating to quality of life and self-efficacy across all clients. The qualitative findings fit very well the results of our former cross-sectional qualitative study, where patients reported as perceived effects of spiritual healing (1) changes in sensations and feelings, (2) changes of self-concepts and values, and (3) changes of medical symptoms and complaints [8]. Based on both our studies we hypothesize that, besides instant relaxing effects, spiritually or religiously oriented clients may utilize spiritual healing treatment to change their life, reframe meaning, increase empowerment and self-control. This may reduce stress and decrease the intensity of complaints and diseases. A central element of healing, in the perspective of our clients, is the feeling of connecting to a transcendental source such as god, angels, light or love [8].

Our hypothesis from the qualitative data is that increased well-being, relaxation, spiritual reframing and change of life may contribute to increased quality of life and also mental and consequently physical health status. The additional quantitative data of our pilot fits this hypothesis. On the visual analogue scale, symptomatic improvements were observed in clients with pain. The short version of the WHOQOL-BREF has been shown to be a cross-culturally valid assessment tool for measuring four domains of quality of life: physical, psychological, social and environmental. At baseline, the clients scored below the German average for women between 46 and 55 years of age [10] for the physical domain (means: $60.7 \pm 23.3$ for our sample vs. $77.1 \pm 16.7$ in the German average), the psychological domain $(48.2 \pm 13.8$ vs. $73.4 \pm 15.3$, respectively), the social domain $(56.0 \pm 9.3$ vs. $72.2 \pm 19.1$, respectively), but not for the environmental domain ( $72.3 \pm 11.5$ vs. $70.2 \pm 13.8$, respectively). After 6 months, the clients almost reached the average for all four domains (Table 2).

The General Self-Efficacy Scale is a 10-item psychometric scale that was designed to assess optimistic selfbeliefs used to cope with a variety of difficult demands in life. It especially refers to personal agency, the belief that successful outcomes are a result of one's actions [21]. At baseline, the clients had lower scores on the General SelfEfficacy Scale compared to the German average for females between 41 and 60 years of age $(24.4 \pm 4.9$ vs.
$28.8 \pm 4.9$, respectively) but reached the German average after 6 months $(30.5 \pm 7.1)$ [22].

Sense of coherence is the core construct of Antonovsky's salutogenetic model. SOC has three components: (1) comprehensibility: a belief that things occur in an orderly and predictable fashion and a sense that you can understand the events in your life and reasonably predict what will occur in the future; (2) manageability: a belief that you have the skills or ability, the support, the help or the resources necessary to take care of things and that things are manageable and within your control; (3) meaningfulness: a belief that things in life are interesting and a source of satisfaction, that things are really "worth it" and that there is good reason or purpose to care about what occurs $[8,15]$. On the SOC-13, our clients were below the German average for women between 41 and 60 years of age at baseline ( $49.3 \pm 11.6$ vs. $64.4 \pm 10.95$, respectively), but almost achieve the reported average after 6 months $(58.3 \pm 19.0)$ [23].

In contrast, the pre-post comparisons of sense of coherence, and the spirituality (SpREUK) showed inconsistent results. SpREUK is a contextual 15 -item questionnaire and differentiates three factors: search (for support/ access), trust (in higher guidance/source) and reflection (positive interpretation of diseases). The questionnaire is a good tool for assessing patients' interest in spiritual/religious concerns. Büssing et al. [13] reported demographic data and SpREUK scores of 257 subjects with medical histories. In comparison with the Büssing et al. [13] sample, our female clients clearly had higher search scores $(69.3 \pm 39.5$ vs. $54.7 \pm 26.0$ for clients and average female patients, respectively), which increased further over time to $79.2 \pm 22.2$ after 6 months. This change could reflect the spiritual search and openness of the clients in this study that lead them to the spiritual healers. Scores for the trust and reflections domains were similar to those reported by the Büssing et al. [13] study. However, trust scores increased over 6 months from $65.0 \pm 30.0$ to $78.3 \pm 25.4$. The large standard deviations show that the scores in the 6 clients were very heterogeneous and should be interpreted with caution.

The Consultation and Relational Empathy (CARE) measure was originally developed as a tool to assess patients' perceptions of relational empathy in the patientdoctor dyad [24]. We adapted this questionnaire to apply to the healer-client relationship. Empathy measures remained unchanged throughout the observation time. Mercer et al. [25] has reported that for general practitioners in UK, the mean score from female patients between 45 and 60 years of age was $40.7 \pm 7.0$ and $41.8 \pm 8.1$ in the general adult population. Clients in the present study reported mean scores higher than those reported by Mercer et al. [25], between 45 and 47, which indicate a high level of empathy (range: 30-50). This may reflect the empa- 
thetic approach used by the healer throughout the treatments. However, it should be noted that the questionnaire was made for doctor-patient relationships, but we adapted the questionnaire to suit the healer-client relationship measured in this study. In this case, study, spirituality seemed to have been less important than we initially assumed. In our previous study, we concluded that healing treatments, healing experiences and therapeutic talks with healers may have resulted in a process of spiritual reframing, that may have helped clients to activate resources, process change and increase their self-efficacy and empowerment [8]. In this study, the main motive for seeking a spiritual healer was not a spiritual quest but rather the need to alleviate medical or psychological complaints. Relaxation, connecting to transcendent sources (e.g., "filling up with energy"), increasing self-understanding, self-experience and self-acceptance, and making psychological and social life changes were reported as important factors for healing. Still, 4 clients entered the therapeutic process with the healer with a spiritual attitude and reported an encouragement of their spiritual attitude as well as support in dealing with their problems during the therapeutic process.

However, as a pilot study using mainly a qualitative approach and supplementing with quantitative questionnaires in a very small sample of participants, this study has several limitations. Because it is a very small pilot case study with no control group, the results should be interpreted with caution. The results of this study are purely descriptive and do not allow for the drawing of causal inferences about clinical efficacy or effectiveness. Also, the recruitment of clients by the healers itself might be seen as a potential community bias. They may have selected clients being more responsive to their first suggestions at the phone or even being more spiritual orientated. However, the fact that only new clients were allowed that had never been to the healer before and not had a treatment by the healer before should have reduced this bias. Another limitation is that all clients were women. This is a typical finding for complementary medicine therapies, but the inclusion of male clients might have changed the qualitative and quantitative findings.

A strength of this study was the additional use of quantitative questionnaires, which allowed us to combine and compare healers' and clients' narratives with data from questionnaires. This naturalistic approach, including selecting only clients who had not participated in previous healing treatments, allowed us to observe naturalistic healing settings and minimize potential community bias.

Many of the quantitative studies on spiritual healing showed inconclusive or heterogeneous results. Spiritual healing itself is not well understood and remains even difficult to define. Qualitative research strategies might help to better understand the phenomenon and to develop better hypotheses and study designs [25]. When designing this pilot study, we believed that a mixed methods approach combining qualitative and quantitative methods would be best suited to get broader outcomes. The results of this study support this approach.

Spiritual healing sessions are usually seeked by a small subgroup of the population, especially by those individuals who look for spiritual answers to their complaints and diseases. Therefore, a naturalistic research design appears to be crucial, but the results will not be transferrable to more sceptical and/or non-religious individuals who will not make use of the respective setting and the meanings offered by the healers.

For future prospective studies on spiritual healing having much larger samples, we believe that - as quantitative global outcomes - quality of life, self-efficacy and intensity of complaints on a visual analogue scale are suited best to describe the changes patients reported and that they could be used in addition to qualitative observations. Based on our studies, we hypothesize that the WHO Quality of Life Questionnaires may be especially useful for measuring general quality of life in a cross-cultural population of clients using spiritual healing. Quality of life is defined and constructed by WHO researchers as "an individual's perceptions of their position in life in the context of the culture and value systems in which they live and in relation to their goals, expectations, standards and concerns" [26, 27]. The WHO has also developed the WHOQOL-SRPB BREF Questionnaire, which could be another useful assessment tool for future research [28] on spiritual aspects of healing.

\section{Conclusion}

In this small case study, clients receiving spiritual healing reported increased psychological and physical wellbeing in the qualitative interviews and felt empowered to change their lives. The questionnaires indicated improvements in disease symptoms and quality of life. The typical clients who visit healers are usually spiritually or religiously oriented and may utilize spiritual healing treatment to relax, change their life, reframe meaning and increase empowerment and self-control, which may improve quality of life, well-being and health. For future quantitative studies, global outcomes such as quality of life, self-efficacy and intensity of complaints on a visual analogue scale may best reflect the reported and perceived changes.

\section{Acknowledgements}

We thank all participating healers and clients for their trust and participation. We thank Katja Icke for her support in data management and statistical analysis. We thank the Goerdt-Stiftung for 
funding. We thank Florian Jeserich and Christine Holmberg for their valuable comments and ideas regarding the qualitative analyses and on the topic of spiritual healing.

\section{Statement of Ethics}

The study was approved by the ethics committee of the Charité - Universitätsmedizin Berlin (EA1/238/10;29.07.2013).

\section{Disclosure Statement}

The authors declare that they have no competing interests.

\section{Funding Sources}

The study was funded by the Goerdt-Stiftung im Stifterverband für die Deutsche Wissenschaft - Deutsches Stiftungszentrum in Essen, Germany. The funding sources had no role in the design and conduct of the study, collection and management, analysis, and interpretation of the data, or preparation, review or approval of the manuscript.

\section{Author Contributions}

Study concept and design: M.T., C.W., F.B., B.S. Data management: B.S. Statistical analysis: M.T. Qualitative analysis: M.T., F.B., B.S. Interpretation of data: M.T., B.S., F.B., C.W. Obtained funding: C.W., M.T. Drafting the manuscript: M.T., B.S., F.B., C.W. All authors read and approved the final manuscript.

\section{References}

1 Benor DJ. Spiritual healing: a unifying influence in complementary therapies. Complement Ther Med. 1995;3(4):234-8.

2 Brown CK. The integration of healing and spirituality into health care. J Interprof Care. 1998;12(4):373-81.

3 Stöckigt BM, Besch F, Jeserich F, Holmberg C, Witt CM, Teut M. Biographical similarities between spiritual healers and their clients in Germany - a qualitative study. Anthropol Med. 2015;22(2):177-90.

4 Stöckigt BM, Besch F, Jeserich F, Holmberg C, Witt CM, Teut M. Healing relationships: a qualitative study of healers and their clients in Germany. Evid Based Complement Alternat Med. 2015;2015:145154.

5 Voss E. Mediales Heilen in Deutschland: Eine Ethnographie. Berlin: Reimer Verlag; 2011.

6 Obrecht A. Die Welt der Heiler: Die Renaissance Magischer Weltbilder. Wien: Böhlau Verlag; 1999.

7 Obrecht A. Die Klienten der Geistheiler. Vom anderen Umgang mit Krankheit, Krise, Schmerz und Tod. Wien: Böhlau Verlag; 2000. pp. 207-32.

8 Teut M, Stöckigt B, Holmberg C, Besch F, Witt CM, Jeserich F. Perceived outcomes of spiritual healing and explanations - a qualitative study on the perspectives of German healers and their clients. BMC Complement Altern Med. 2014 Jul;14(1):240.

9 Biernacki P, Waldorf D. Snowball sampling: problems and techniques of chain referral sampling. Sociol Methods Res. 1981;10(2): 141-63.

10 Angermeyer MC, Kilian R, Matschinger $\mathrm{H}$. WHOQOL-100 und WHOQOL-BREFHandbuch für die Deutschsprachigen Versionen der WHO Instrumente zur Erfassung von Lebensqualität. Göttingen: Hogrefe Publishing; 2000.
11 Schwarzer R, Jerusalem M, editors. Skalen zur Erfassung von Lehrer- und Schülermerkmalen: Dokumentation der Psychometrischen Verfahren im Rahmen der Wissenschaftlichen Begleitung des Modellversuchs Selbstwirksame Schulen. Berlin: Freie Universität Berlin; 1999.

12 Büssing A. Spirituality as a resource to rely on in chronic illness: the SpREUK questionnaire. Religions (Basel). 2010;1(1):9-17.

13 Büssing A, Ostermann T, Matthiessen PF. Role of religion and spirituality in medical patients: confirmatory results with the SpREUK questionnaire. Health Qual Life Outcomes. 2005 Feb;3(1):10.

14 Abel T, Kohlmann T, Noack H. SOC-Fragebogen. Revidierte Fassung der Übersetzung von Noack und Bachmann (1987). Bern: Abteilung für Gesundheitsforschung des Instituts für Sozial-und Präventivmedizin; 1995.

15 Antonovsky A. Unraveling the Mystery of Health. San Francisco (CA): Jossey-Bass; 1987.

16 Jeserich F. Can sense of coherence be modified by religious/spiritual interventions? A critical appraisal of previous research. Interdiscip J Res Relig. 2013;9:1-36.

17 Schumacher J, Brähler E. Sense of Coherence Scale von Antonovsky (SOC-Skala). Leipzig: Universität Leipzig; 2000.

18 Neumann M, Wirtz M, Bollschweiler E, Warm M, Wolf J, Pfaff H. Psychometrische Evaluation der deutschen Version des Messinstruments "Consultation and relational empathy" (CARE). Psychother Psych Med. 2008; 58(1):5-15.

19 Mercer S. The CARE Measure. Glasgow: University of Glasgow; 2004.

20 Hsieh HF, Shannon SE. Three approaches to qualitative content analysis. Qual Health Res. 2005 Nov;15(9):1277-88.
21 Schwarzer R, Jerusalem M. Generalized selfefficacy scale. In: Weinman J, Wright S, Johnston M, editors. Measures in Health Psychology: A User's Portfolio Causal and Control Beliefs. Windsor, UK: NFER-NELSON; 1995. pp. 35-7.

22 Hinz A, Schumacher J, Albani C, Schmid G, Brähler E. Bevölkerungsrepräsentative Normierung der Skala zur allgemeinen Selbstwirksamkeitserwartung. Diagnostica. 2006; 52(1):26-32.

23 Schumacher J, Gunzelmann T, Brähler E. Deutsche Normierung der Sense of Coherence Scale von Antonovsky. Diagnostica. 2000;46(4):208-13.

24 Jonas WB, Crawford CC. Science and spiritual healing: a critical review of spiritual healing, "energy" medicine, and intentionality. Altern Ther Health Med. 2003 Mar-Apr;9(2): 56-61.

25 Mercer SW, McConnachie A, Maxwell M, Heaney D, Watt GC. Relevance and practical use of the Consultation and Relational Empathy (CARE) Measure in general practice. Fam Pract. 2005 Jun;22(3):328-34.

26 WHO. WHOQOL-BREF - Introduction, Administration, Scoring, and Generic Version of the Assessment - Field Trial Version. Geneva: World Health Organization; 1996.

27 Skevington SM, Lotfy M, O’Connell KA; WHOQOL Group. The World Health Organization's WHOQOL-BREF quality of life assessment: psychometric properties and results of the international field trial. A report from the WHOQOL group. Qual Life Res. 2004 Mar;13(2):299-310.

28 Skevington SM, Gunson KS, O'Connell KA. Introducing the WHOQOL-SRPB BREF: developing a short-form instrument for assessing spiritual, religious and personal beliefs within quality of life. Qual Life Res. 2013 Jun; 22(5):1073-83. 